\title{
ON THE ISSUE OF INTERNATIONAL UNITY AND SYNERGY OF THE COMMUNIST MOVEMENT
}

Keywords: communism, Communist Party of China, People's Republic of China, Marxism, political movements

\begin{abstract}
The subject of the analysis is the development of program and organizational changes in recent decades in Communist Party of China. In particular, the international context and potential opportunities for international cooperation of communist parties and the creation of a new global organization are considered. The publication also considers the historical background of the functioning of the Communist International. It is stated that Communist Party of China possess own independent way of building of socialism. Article main conclusion is that international communist movement should change its relations with the Communist Party of China and cooperate together.
\end{abstract}

\section{INSTEAD OF INTRODUCING}

The new stage of the class struggle is not only in Poland, but in Europe and in the world, requiring us to force our activity on the international stage. We have discussed many years about the new International, but there has been no results. The main cause is the collapse of the Communist Party of the Soviet Union, of the USSR, the Peoples Democracies in Europe at the end of $20^{\text {th }}$ century, especially danger of new revisionism, opportunism and nationalism. The political initiative become capitalism, imperialism

1 Professor emeritus of the Universoty of Wrocław, z.wiktor@gazeta.pl 
with the new hegemony of United States of America and in Europe under increased leadership of the united Germany in European Union.

The dramatic events were the collapse of German Democratic Republic and Czechoslovak Federal Socialist Republic. The socialist community was falling. With the fall of CPSU under M. Gorbatchov and especially B.Yeltzin is collapsed the „semi-socialist” policy of former leaders of USSR -N.Khruchchov and L.Breshnev, was not supported by working peoples. As a hegemonic new strata in the Soviet Union increased new privileged strata was steered by also privileged and uncontrolled (by workers) party apparatus.

After the collapse of the "real socialism” in USSR and Peoples Democracies in Europe many communists and worker parties remained as political orphans. It was dramatic and difficult not only for these parties, but also for the working class in their countries and in the world. The capitalism and imperialism become new great political and ideological success and new forces. There were more exploitation of the working classes and trends to the world hegemony and new wars for the new partition of the world. It is very difficult for working peoples since they are exploited and oppressed by imperialism countries.

We as the communist parties and movement must to find a new ideological and political exit from this dark class situation.

We must go beck once more to the our splendid history of international communist movement and to find in history the origins and causes of our former power and unity. We must it find also in the contemporary time sources of the power and unity communist movement. We must especially to give the attention to the Communist Party of China, who since 70 years ago walks it by own path of the anti-capitalist and democratic revolution and has built the socialism with Chinese characteristics, especially in the last 40 years.

\section{FROM A HISTORY OF MOVEMENT}

In our opinion it is actually a Marx and Engels slogan: Proletariat of all countries, united! Since 1848 („Manifesto of the Communist Party”) 
remained true, because Marxism and communism are international and our class struggle, our tasks and main goals are not separated but are common for the working peoples in the whole world.

The $1^{\text {st }}$ International - the origins. Its goal of the International workers movement was actual as a organizing question still in the second half of the 19ts century. It was established in 1864 by workers' trade unions, mutual support societies, political and cultural groups and conspiracy organizations.

The $1^{\text {st }}$ International was founded as an international organization with sections and poles in different countries. The 1. International is joined with quantity and quality of the workers movement and its historical result of the Paris Commune in 1871. This the time that capitalism was passing into its highest stage - imperialism.

The Second International was formed on July 1889 in Paris in the period of rapid development and expansion of the global capitalist system, with the formation of monopoly and finance capital as well as the fervent development of the trade unions movement. From this time to 1914 Marxism had become the dominant trend in the labor movement, but reformist, anarcho-syndicalist and other opportunist forces had an influence and during the years within this period it become the predominance, especially reformism.

The $2^{\text {nd }}$ International collapsed in reality in 1914 , when most of the leaders of the $2^{\text {nd }}$ International betrayed the communist ideals and passed on the site of class enemy. It introduced the collapse of the $2^{\text {nd }}$ International and it ended with the breaking out of World War I.

The positive side of Second International was the establishing many worker and social democrat national parties, which in the first time of this period were been building on the ideological level class struggle, socialist revolution and consequent struggle against capitalism and for the socialism.

The beginnings of the Third International were established in the terrible years of the World War I and victorious October Revolution 1917 in Russia. Thanks to the international revolutionary initiative of the Social Democratic Party (bolsheviki) of Russia under leadership of Vladimir I. Lenin, which in the next years changed the name of Party of Communist Party (bolsheviki) of Russia. 
The foundation Congress of the Third International (Communist) took place in Marche 1919 in Moscow in new socialist state - Russian Federal Socialist Republic. The founder of new International welcomed the victory of the proletarian revolution in Russia and the Congress stated: „A new epoch is born, the epoch of the dissolution of capitalism, of its inner disintegration, the epoch of the communist revolution of the proletariat".

The main international slogan was: „Long life the Communist World Revolution!"

The Third International played a great role in the development and the popularization of the marxism-leninism, in the establishing of new revolutionary parties and in class struggle against capitalism and imperialism, the danger of war and for the peace. Third International propagated the successes of the socio-economic and political policies of the Soviet Union and its positive role in the defending of peace in the time of aroused fascism and the danger of war. The Third International played special positive activities in the establishing of the communist parties in the colonial and semicolonial countries, for example China, India, Netherlands-Indian, Indochina, Iran, Turkey and others. Special attention needs to be paid to the Communist Party of China - July 1921, who rapidly advanced into a great revolutionary communist party. After 28 years it has gained great victory. Similarly Korean, Indochina (Vietnam) and former Mongolian.

Other forms of activity of Third International were the development of the theory of Marxism-Leninism. The Soviet scientists were finding many possibilities to save and to publish many manuscripts and other documents of Marxs, Engels, Lenin and Stalin and other socialist authors from USSR and abroad. The capital of the Third International was Moscow. Many persecuted communists from reactionary states came here and it became a political asylum, providing help and support. The Third International and Soviet Union were named the fatherland of world proletariat.

The Third International played the importance role in the struggle against imperialism, fascism, in the building of the People's Fronts and for the defense of the Soviet Union as a first socialist state.

The Third International existed to May 1943. It was organizing on the principle of the democratic centralism and all communist parties were its 
members. In the consequences the Third International was a world superparty. This principle was the organizing result of the loose organization of the former Second International, but in the next time was favourable to centralism (without democracy). This principle was effective for the early united activity of the communist parties, because it focused and centralized all progressive political forces in the struggle against capitalism, imperialism fascism, and for the democracy and socialism. However, it limited the independence of individual parties and it was unofficial criticised. especially during the controversial time was after death of W.I. Lenin -Jan. 1924.

The illustration of this situation and tendency were the congresses of Third International. In the time of Lenin congresses were organized every year. After death of Lenin the $5^{\text {th }}$ Congres took place in 1924, the $6^{\text {th }}$ Congress -1928 , and the last $7^{\text {th }}$ Congress -1935 . During this period the leading political and ideological position became the Executive Committee of International, which was more bureaucratic. It was in the reality "governed" by the Third International. It was the time, when in the Soviet Union increased many new contradictions and tensions, which had the sources in foreign policy (fascism) and in inner policy (the transition of the state capitalism to the centralised socialist economy) and the danger of war. Dramatist event for the Polish communists was the dissolution of the Communist Party of Poland by the Executive Committee of Third International under false charge (1938).

In May 1943 in the difficult situation of the war for the Soviet Union against fascist Germany the Executive Committee of Third International dissolved the Third International. In this time (after victorious battle by Stalingrad) were established many new communist and worker parties, which were going to more independent policy from leading international Center. It played also role the factor of influence of the capitalist allies, especially USA and Great Britain, payed the price for the promise of the opening of the Western front and the separated communist parties were more under control of capitalist regimes.

The special attention we should to given to the Communist Information Bureau (Cominform), which was existing from 1947 to 1956. It was the proof of the organizing of the new form of the unity of the interna- 
tional communist movement after collapse of cooperation between West allies with the Soviet Union and the increase of the cold war. It was limited form of the union of communist parties, more a coordination bureau of WKP(b), communist and worker parties of Peoples Democracies and Communist Party of France and Italy as its members. In fact the Cominform discontinued of the activity after death of Stalin in March 1953. Formally the Cominform was dissolved 1956 by its members after XX. Congress of CPSU and new ideological and political situation in Soviet Union after death of Stalin. The new leadership of the CPSU by N.Khrushchov was to go step by step to direction of new revisionism and opportunism.

In the period of 1956 to 1989 , there were no new international or other organisation of the unity communist and worker movement. It was very different and contradictions time from the Cold War to the time of peace cooperation between capitalist and socialist states and communist forces and peace struggle against the heated wars in Korea, Vietnam, in Middle East and many others. Fascism and imperialism were after World War II weakened and socialist communities were in Europe, Asia and afterwards in America (Cuba). With the help and support of the socialist states many anticolonial and anti-capitalist revolutions broke out. The world was divided into socialism, capitalism and the so called third world countries. The plurality was organized in movement of unengaged states, many of their introduced under influence and support for socialist states the democratic and partial socialist relations.

In this time the main role in organising of the international unity of the communist movement played the world, continental and local conferences of the communist and worker parties, for example in Moscow, Berlin, Prague and many others. The leading role in the conferences played CPSU, what had good but also negative results in direction revisionist and opportunist tendency in other parties. CPSU under leadership of N. Khrushchev was injected by new revisionism and opportunism and party step by step was going to the ideological and political collapse, which took place in the time of Secretary M.Gorbachow and B.Yelzin (1985-1991). This time we can describe this as a bureaucratic system of the semisocialism, what was the base of they near collapse. It was the bitter lesson 
for the worker movement and all progressive forces of mankind in the last years of XX century.

The complicated problems of this period were analyzed and described in the book by prof. Mieczysław Rakowski and Zbigniew Wiktor "The history of struggle for classless society (proletariat) and its perspective (from Marx until near future). Poland-Warsaw-Wrocław, 2019, p. 330 (Internet-script in English).

\section{THE POSITION AND INTERNATIONAL ROLE OF THE COMMUNIST PARTY OF CHINA}

In despite of these negative tendencies of the communist movement not all of the communist movement collapsed. Communist Party of China was going its own independent way to building of socialism and its development to increasing of socialism. but no without the errors, especially in the Mao Zedong period.

Regarding the building of communism attempts to cut corners in China by the people's communes in the countryside, with the assumption of full centralization of management in communes, while there were extreme egalitarian distribution at very low levels, it accounted to brake rapid development of agriculture in the small areas of the person and low mechanization. It barely followed during the period 1958-1978 for population growth, providing in only „the iron rice bowl”. China' s peasant masses went to the people's communes believing the party, whose policy was however in this era completely irrational.

It might be assumed that it was to raise the general standard of living, reduce the differences in income, democratization of power and reduce of social differences, it will be possible in the future, when socialism will prevail all over the world, the transformation of the state in the communist social self-government.

KPSU on the $22^{\text {nd }}$ Congress denied on the need for the dictatorship for the proletariat (or more broadly the issue - the dictatorship of the lower social strata). It increased the attack of Khrushchow and this group against the scientific socialism under the slogan of a battle against „Stalinists” and 
"Stalinism" in the CPSU and in international communist movement. The differences between the CPSU and CPC were increased and in 1960-1961 they were divided. It was the great victory for imperialism and in the reality after the collapse of CPSU and the Soviet Union, the whole international communist movement collapsed.

But not all, CPC founded the new tactics on the BUILDING of the socialism - „socialist market economy”, but not the mature socialism. The strategy had remain consequent. It is communism. Chinese communists say, we are doing it like Lenin and Stalin in 1920-1929. They introduced the state capitalism, but now the Chinese took this in giant scale, in other historical international relations.

The CPC introduced not only socialist market economy but also the policy of open up foreign capital, not as a dependent semi-colonial country. The foreign capital must respect the law-political system of PR China and the principle o the leading role of the Communist Party of China. The great capitalist monopolies, corporations and banks became from China big profits, but Chinas working class and Chinese economy become the new factories, new direct investments, which gave every year more than 10 million new modern jobs and the same amount of moderated jobs, new technologies, new modern industries and services.

The Global Product in China increased in last 40 years more than 30 times and in all period of PR China (70 years) 450 time (!). The PR of China had in the last 40 years removed from poverty 700 million peoples and 400 million introduced to middle income. The Global Product in 2018 was 13,6 billion dollars. If counted in comparable money power $(50 \%$ more) it is about 20 billion dollars, which keeps the China's economy as the $2^{\text {nd }}$ (maybe 1 position?) economy in the world.

The prospect of the China's development was declared on the $19^{\text {th }}$ Congress of CPC in October 2017. The decisive victory is to build a moderately prosperous society in all respects by 2021 and to a modern socialist China by 2049. It is the real perspective for the 1,5 milliard peoples (about $20 \%$ of mankind).

For the past more than 40 years the People's Republic of China has had a great social and economic, which made development in many aspects, which made the lives of hundreds of millions of inhabitants better worthy 
and more honorable. The population of working class in industry increased to more than 300 million peoples. New strata of services emerged, which was one of the main division of the contemporary proletariat.

The Communist Party of China did not collapse politically and ideologically, Its program and political praxis is adequate to the building of the fundaments (base) of socialism in extremely poor economic conditions, where the transition period will be exist even for 100 years.(sic!) It is the great program change of the praxis of the building of socialism in a developing country. Also in comparison to the Marx and Engels idea since 1846, who declared the proletarian revolution and transition to communism will be ,auf einmal und gleichzeitig”.

The experience of the Commune of Paris delivered many arguments to the length and autonomous characteristics of the transition period. It confirmed the great experiences and many years of class struggle after the October Revolution in 1917. It is the great programmatic change of the periodization of the communist formation. We are living in other period of capitalist formation in comparison to the Marx time, It was liberal capitalism, in time of Lenin was imperialism and now we are living in oligarchy-global capitalism, but it exists in very different world with socialist states, especially China and hundreds developing postcolonial states, they drifts to economic and political independence.

In this situation the Chinese ,socialist market economy" is the cooperation of economically weaker socialist states with strong foreign capital, but without acknowledge of dependency. This what happened with Lenin and Stalin in Russia and in the USSR in 1920-1929 (The period of NEP - „novaya ekonomicheskaya politika”). I repeat, we are living in different stage of capitalism and CPC is fully legitimate to take this policy and build the socialism with Chinese characteristics. Others can't. The theory and praxis of the Chinese building of socialism and to strive to communism agrees with and are in consistency with the general theory of scientific communism.

CPC liquidated the CENTRAL planned economy, but general it not liquidate the planned economy, which has not indicative but steered characteristics. Many economic problems organizing the market. Its marks the cooperation of the two principles: „,invisible hand of market" with the 
"visible hand of government". This system has bring in China colossal economic results for the working class and others working peoples.

In my opinion now $\mathrm{CPC}$ has the great potential not only socio-economical, but also political and ideological. China has risen to be a great partner to the dissolution of giant world problems and it declared the responsibility for the problems of the world. No great problem of the world can be dissolved without China. The way of the building more egalitarian socialist system is very attractive for so called poor-developing countries of Asia, Africa, South America and for the Russia and Eastcentral Europe. The great promotion of this program is the new Chinese initiative of the One Belt One Road (OBOR), a policy that provided the great help and support for more than 100 countries in the world. CPC has all requirements to be a new center of international not only the communist movement, but also all progressive forces in the world.

An others problem is, can CPC could take upon itself the material and organising functioning of a common center of international communist movement? For the past 40 years policies have open up and socialist market economy China become great socio-economic and political development. However this is the result of China being has behind the main contradictions between the world of capitalism and world of socialism (USSR) and the imperialist centers of bourgeoisie, who saw the „socialist market economy" as a direct way towards capitalism. It was not true. The CPC has not betrayed the socialism and communism, but it exploited the economic cooperation with big capital foreign and owner for the Chinese rapid development and the technological modernization of owner economy.

The development of Chinese economy is great globally, but in comparison to working efficiency is in industry and services 4,5 time lower than in USA and West Europe, and in agriculture many many time more. It marks China must in the next 30 years to attain a level of full modern, innovative highest science-technological economy in the world. Here is the source of the careful international policy of China, because imperialism is very danger and it has military superiority. The main problem of progressive mankind is to remain the peace in world and no to admit to global war. 
Of course, the secondary problem is the rebirth of the new national bourgeoisie, new milliards and many millionaires, who have control about $2 / 3$ of the GDP (property?). However as a social class Chinese bourgeoisie has no official representing party, which could represent the interest of its class. Even so it has unofficial influence on the political life by the big corruption and official by the Central Consultative Commission (a kind of the Front of National Unity).

The counterrevolution in China is really danger, but it is strong in keeping aloof of political power. The transition period between capitalism and socialism in China is a period of permanent class struggle between victorious working class and other working peoples and the continuation of the strong economic position of the class bourgeoisie. It is relatively long period. The class struggle in People's Republic of China has been in the last years more acute, what was confirmed by the leader decisions and main documents of the $19^{\text {th }}$ National Congress of CPC.

Now after 40 years of the introduction of the new policy, PR China opens up and has risen to the first - second place in world economy ranking (but in different structures as in USA or in EU). It has risen not only as first competitor but also as the main great class enemy of the capitalist world.

In this situation the international communist movement should change its relations with the Communist Party of China and cooperate together in the common struggle against imperialism, capitalism and war, for peace and solidarity in common goal to socialist revolution and the building of socialism.

In my opinion now, in contemporary epoch CPC and the People's Republic of China are in contemporary communist movement, taking obligations of the united forces in the international communist forces, especially in developing countries. Of course, this does not mean, that the place of the new International must to be in Beijing or Shanghai. It can also to be in well - organized, democratic and governed by progressive regime with a strong communist party in one of developing country. 


\section{BIBLIOGRAPHY:}

„Beijing Review”. A News Weekly Magazin, Beijing 20017-2019.

„Brzask”. Pismo Komunistycznej Partii Polski. Dąbrowa Górnicza.

Lin, Weida (ed.) (2016). Chińskie ABC. Wydawnictwo Poligraf.

Communist Party of Greece. 100 years of the Communist International. Statement of the CC of the KKE, September 2019.

„100 years to the Communist International and tasks of the Communist movement today". Final Declaration of the participants of international conference Communist Worker Party of Russia. September 2019.

Lenin, W. I. (1952-1974). Dzieła wszystkie, Wydanie 1. Warszawa.

Marks, K., Fryderyk, E. (1965-1975). Dzieła wszystkie.Warszawa.

Międzynarodowy Ruch Robotniczy (1976). T.1. Wiek XIX.-1945; T.II. 1945-1975. Książka i Wiedza, Warszawa.

Pikety, T. (2013). Kapitał w XXI wieku, Warszawa.

„Struggle for Communism. 100 years of Political Heritage” CP of Turkey, February 2019, September 2019.

Rakowski, M., Wiktor, Z. (2019). History of struggle for classless society and its perspective (from Marx until near future). Komputeropis, Warszawa-Wrocław.

Wiktor, Z. ( 2019). Chińska wizja budowy socjalizmu w świetle materiałów XIX Zjazdu KPCh. In. J. Marszałek-Kawa, M. Bidziński (ed.), Wektory zmian w polityce Chińskiej Republiki Ludowej w okresie rządów Xi Jinpinga. Wydawnictwo Adam Marszałek, Torun.

Xi Jinping (2017). The Governance of China. T.1, 2, Foreign Languages Literature, Beijing. Xi Jinping (2019). Zarządzanie Chinami I, Wydawnictwo Adam Marszałek, Foreign Languages Press, Toruń. 
REVIEW 
